\title{
Comment on "Mucin gene polymorphisms are associated with endometriosis in Korean women"
}

\author{
Sora Yasri ${ }^{1} \cdot$ Viroj Wiwanitkit ${ }^{2}$
}

Received: 21 December 2019 / Accepted: 26 February 2020 / Published online: 9 March 2020

(c) Springer-Verlag GmbH Germany, part of Springer Nature 2020

\section{Dear Editor,}

We read the publication on "Mucin (MUC) gene polymorphisms are associated with endometriosis in Korean women" with a great interest [1]. Kim et al. concluded that "The MUC1 genotype may not be correlated with endometriosis susceptibility. However, MUC4 polymorphisms are associated with the risk for endometriosis in Korean women [1]." In fact, the single-nucleotide polymorphism (SNP) of MUC results in molecular change, and the molecular change further results in the alteration of phenotypic expression. This change in, due to either, MUC1 or MUC4 SNPs should affect the final phenotypic expression. Nevertheless, Kim et al. focused on only MUC1 and MUC4 SNPs. There are also other genetic polymorphisms that might associate with endometriosis [2]. The examples of those genetic polymorphisms are tumor necrosis factor- $\alpha$ gene-1031T/C promoter, vitamin D-binding protein and Interleukin 1 alpha polymorphisms [3, 4]. The effects of other possible genetic confounding factors should be assessed in the future studies.

\section{Compliance with ethical standards}

Conflict of interest The authors declare no conflict of interest.

Sora Yasri and Viroj Wiwanitkit contributed equally.

This comment refers to the article available online at https://doi. org/10.1007/s00404-019-05409-0.

Sora Yasri

sorayasri@Outlook.co.th

KMT Primary Care Center, Bangkok, Thailand

2 Dr DY Patil University, Pune, India

\section{References}

1. Kim JH, Kim TH, Kim YS, Jang WC, Ryu A, Hwang JY, Lee HH (2019) Mucin gene polymorphisms are associated with endometriosis in Korean women. Arch Gynecol Obstet. https://doi. org/10.1007/s00404-019-05409-0 (Epub ahead of print)

2. Méar L, Herr M, Fauconnier A, Pineau C, Vialard F (2019) Polymorphisms and endometriosis: a systematic review and metaanalyses. Hum Reprod Update. https://doi.org/10.1093/humupd/ dmz034 (Epub ahead of print)

3. Drakou A, Mavrogianni D, Ntzeros K, Protopapas A, Drakakis P, Loutradis D (2019) Association between tumor necrosis factor- $\alpha$ gene-1031T/C promoter polymorphism and endometriosis in a European population. Horm Mol Biol Clin Investig. https://doi. org/10.1515/hmbci-2019-0033

4. Cho MC, Kim JH, Jung MH, Cho IA, Jo HC, Shin JK, Lee SA, Choi WJ, Lee JH (2019) Analysis of vitamin D-binding protein (VDBP) gene polymorphisms in Korean women with and without endometriosis. Clin Exp Reprod Med 46(3):132-139

5. Badie A, Saliminejad K, Salahshourifar I, Khorram Khorshid HR (2019) Interleukin 1 alpha (IL1A) polymorphisms and risk of endometriosis in Iranian population: a case-control study. Gynecol Endocrinol 28:1-4

Publisher's Note Springer Nature remains neutral with regard to jurisdictional claims in published maps and institutional affiliations. 